Article

\title{
From Zoomers to Geezerade: Representations of the Aging Body in Ageist and Consumerist Society
}

Jacqueline Low $^{1, *}$ and Suzanne Dupuis-Blanchard ${ }^{2}$

1 Department of Sociology, University of New Brunswick, PO Box 4400, Fredericton, New Brunswick, E3B 5A3, Canada

2 School of Nursing, Jacqueline-Bouchard Building, University of Moncton, 18 Antonine-Maillet ave, Moncton, New Brunswick, E1A 3E9, Canada;

E-Mail: suzanne.dupuis-blanchard@umoncton.ca

* Author to whom correspondence should be addressed; E-Mail: jlow@unb.ca; Tel.: +1-506-474-1749; Fax: +1-506-458-7439.

Received: 31 August 2012; in revised form: 17 December 2012 / Accepted: 17 December 2012 / Published: 10 January 2013

\begin{abstract}
This paper is based on an analysis of representations of seniors in the media. In particular, we examine images of the bodies of seniors in the advertising campaigns promoting a product called Geezerade sold in Circle K convenience stores in the Atlantic provinces of Canada in the summer of 2011. We contrast these with images of seniors in the Canadian magazine Zoomer, formally CARP magazine, a magazine published by the Canadian Association of Retired People, a seniors advocacy organization. Following Goffman's arguments in his seminal presidential address to the American Sociological Association, "the Interaction Order", we take the position in this analysis that the body does not determine social practices but none-the-less the body is the sign vesicle that enables interaction. Concomitant however, while the images of bodies we see in the media do not determine the signs given and given off via bodily presentation, they none-the-less provide us with the categories by which we interpret those signs. We conclude that the images in the Geezerade campaign and Zoomer magazine represent a binary model of images of seniors that reflects ageist and classist assumptions about the bodies of seniors. Such a model limits the categories through which we understand the aging body and fails to account for the diversity of seniors' bodies in society.
\end{abstract}

Keywords: ageism; senior’s bodies; images of seniors 


\section{Introduction}

This paper is based on an analysis of images of seniors in the media. In particular, we examined how the bodies of seniors were depicted in an advertising campaign promoting a product called Geezerade sold in J. D. Irving Oil owned Circle K and Couch-tard gas station convenience stores in Quebec and the Atlantic provinces of Canada in the spring and summer of 2011. We contrast these with images of seniors' bodies in spring/summer 2012 issues of the Canadian magazine Zoomer, formally CARP Magazine, a magazine published by the Canadian Association of Retired People, a seniors' advocacy organization. We argue that the images in the Geezerade campaign and in Zoomer magazine represent the two sides of a binary model of images of seniors that reflect ageist and classist assumptions about the bodies of seniors. Moreover, deeper analysis reveals that among negative portrayals of older people in the media, the Geezerade campaign invokes the 'grotesque' as a marketing tool [1]. We use the concept of the grotesque [2] in its classical sense where it refers to a style of cave painting discovered in the late 1600s in Rome and Italy that depicted "unnatural, biomorphic mergings of plant, animal, and human features” ([1], p. 7). We conclude that such a binary model limits the categories through which we understand the aging body and fails to account for the diversity of seniors' bodies in society.

\section{Analyzing Images}

Analyzing images is important as they are among the significant symbols that reflect "what is socially significant" within a culture and through which we give meaning to social life ([3], p. 31). Thus, it is surprising that there has been comparatively little sociological study of images that, According to Smith ([4], p. 42) treat them "as data, worthy of analysis in their own right, and not merely [as] a handy illustrative resource intended only to vivify the serious business of analysis accomplished by the written text” [3,5]. Moreover, of analyses that have been done, most have been concerned with images of gender, race, and, in Said's [6] sense of the term, the other (one who is not only different but also inferior to oneself) $[7,8]$. In contrast, until recently, there have been fewer analyses of images of seniors or their bodies [9-11].

We take a symbolic interactionist approach in this research; a core tenant of which is that meaning does not reside in symbols, rather, meaning is given to symbols. However, and of particular relevance to our analysis, social life is only possible because we come to share the meanings of significant symbols [12]. Thus, symbolic analyses of images "attempt to address the meaningful aspects of visual representations" ([3], p. 32). Likewise, our analysis is aimed at the "contextual meaning of a symbol" whereby a symbol "derives its [meaning in] relation to other symbols as part of a pattern or system," namely, stereotypes of the aging body in contemporary consumerist society [13,14]. Further, following Goffman's arguments in his seminal presidential address to the American Sociological Association, "the Interaction Order", we take the position in this analysis that the body does not determine social practices but none-the-less the body is the sign vesicle that enables interaction [15]. However, also consistent with Goffman's arguments about gender display in his study of gender in advertising, we maintain that while the images of bodies we see in the media do not determine the signs given and given off via bodily presentation, they none-the-less provide us with a limited range of categories by 
which we interpret those signs [15,16]. For Goffman, they are "the culturally conventional portrayals...ordinarily available and noticeable to society members at a glance” and thus limit the range of acceptable bodily presentations available to older adults [4]. In Goffman's classic phrasing:

There is a loose gearing, then, between social structures and what goes on in particular occasions of ritual expression... Participants... are often displayed in rankable order with respect to some visible property looks, height, ...elaborateness of costume... and so forth—and the comparisons are somehow taken as a reminder of differential social position, ... Thus, the basic forms...provide a peculiarly limited version of the social universe, telling us more, perhaps, about the special depictive resources of social situations than about the structures presumably expressed thereby ([16], p. 3).

\section{Methodology}

We take a qualitative approach in this research. Included in our analysis are the images used in the Circle K Geezerdade advertising campaign and images of older adults found in spring and summer 2012 issues of Zoomer magazine. We used ethnographic content analysis [17] of these images as our primary means of generating data, and while not a grounded theory study per se, we also made use of grounded theory analytic techniques including: theoretical sampling of the literature and comparative coding in this research [18]. Such analyses are carried out inductively and hypothesis testing emerges from data analysis in the course of comparative coding [18].

Specifically, we analyzed 274 images of older adults found in the first five digitally available issues of Zoomer magazine (May 2012-July 2012); coding them as positive, negative, or comical. Images of older adults were coded as positive or negative based on stereotypical characteristics of aging [13,14]. Thus, positive images were those where the subjects were depicted as happy, well dressed, and showed no sign of illness or infirmity. Likewise, those coded as negative were images showing older adults in vulnerable positions of illness or mobility impairment; where subjects were frowning, expressing pain, looking down, or presenting a hunched body posture [13,14]. Images coded as comical were those where the magazine's intent was clearly comical, such as the juxtapositioning of an older woman with a much younger man in a romantic situation or images of older adults in neon colored 1950's clothing. We also took note of the frequency of older adults depicted as non-white and as financially distressed. Also included in this analysis are the images depicted in posters used in the Circle K Geezerdade advertising campaign that appeared in convenience stores in Quebec and the Atlantic provinces of Canada in the spring and summer of 2011.

\section{Portrayals of Seniors in the Media}

While there has been an increase in portrayals of seniors and images of aging bodies in the media over time, they remain under-represented particularly in advertising [14,19-21]. When they do occur, it is within the context of a binary model of opposing stereotypes of aging, one characterized by the positive attributes of "virtue [and] self-reliance" and the other by the negative traits of inevitable decline culminating in sickness, “dependency” and death [20,22-24]. 


\section{Positive Images}

Research shows that older adults are increasingly portrayed in a positive light in the media as "well groomed, active, happy and healthy” as well as financially secure ([10], p. 46; [25,26]). Indeed, a sea of khaki, light blue sweaters, sandy beaches, and affluence characterize positive images of aging bodies in all media; particularly in advertising (see Figure 1).

Figure 1. Bank of Montreal Advertisement.

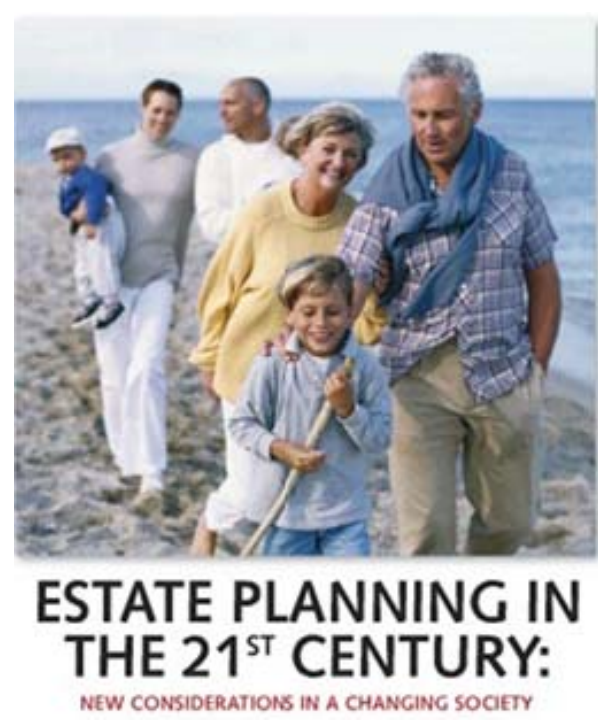

Zoomer Magazine 07/2012, p. 3.

Further, “over time...more modern...images of older people” have emerged where they are portrayed as both active and adventurous as well as healthy and happy [10,27,28]. According to Vespiri, there has been a "shift from acquiring more material possessions toward a desire to purchase enjoyable and satisfying experiences” including adventure travel” ([29], p. 131; [10]) (See Figures 2 and 3).

Figure 2. Article: "Vitality".

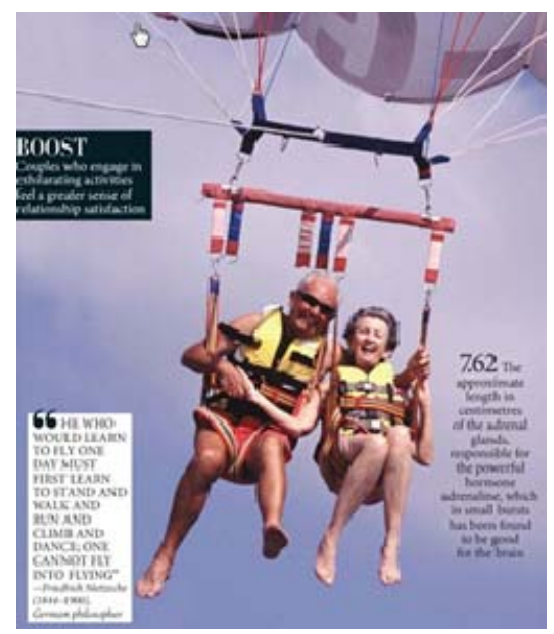

Vassoss, V. Zoomer Magazine 07/2012, p. 35. 
Figure 3. Article: “Taking a Hike”.

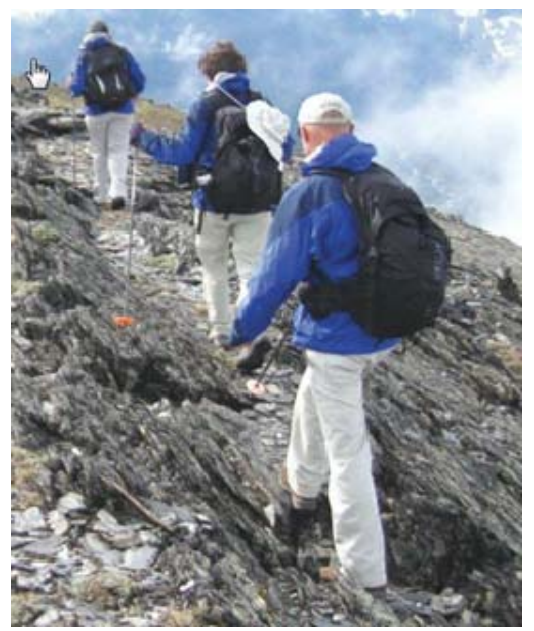

Irvine, D. Zoomer Magazine 07/2012, p. 105.

Concomitant with aging populations worldwide, the number of magazines aimed at older adults has increased [10,30,31]. Lumme-Sandt argues that "the very idea of a $50+$ magazine is to focus on positive aspects of older age" and the Canadian magazine Zoomer typifies such positive portrayals of older people ([10], p. 45). Zoomer magazine, formally CARP magazine, is published by the Canadian Association of Retired People, a seniors' advocacy organization. According to Moses Znaimer, owner of Zoomer magazine and the Canadian broadcaster and media entrepreneur responsible for popularizing the term, a Zoomer refers to a baby "Boomer with Zip" and so called 'Zoomers' represent the 14.5 million Canadians who are 45" and over. As can be seen in the following internet promotion for Zoomer magazine, a Zoomer has the "body of a 65 year old," the "mind of a 45 year old," "the libido of a 25 year old”, the "heart of a teenager”, and "controls 1/3 of all Canadian wealth (see Figure 4).

Figure 4. Online Advertisement for the 2011 Zoomer Media Trade Show.

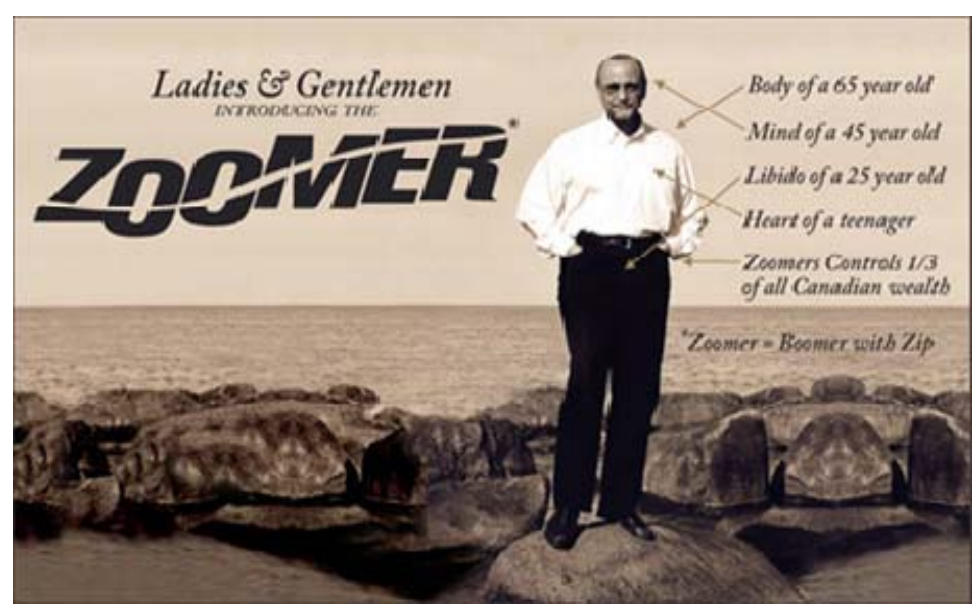

Online Advertisment for the 2011 Zoomer Show, Zoomer Media.

By definition therefore, Zoomers defy the aging process. However, they do so largely via consumption of various products that tout the anti-aging promises of being ageless and recreating youth [32,33]. For example, Zoomer magazine regularly includes advertisements such as Aveno's "Positively Ageless" night cream that features a young and beautiful model [34]. Other advertisements 
promote dental implants that "let you kiss again" or vitamins that allow you to "feel young again," both showing images of broadly smiling, very youthful, older adults [35,36]. Moreover, we found virtually no overtly negative images of older adults in the five issue of Zoomer magazine we examined (see Table 1).

Table 1. Images of Older Adults in Zoomer Magazine March-July 2012.

\begin{tabular}{cccccc}
\hline Images of & \multicolumn{5}{c}{ Zoomer Magazine } \\
\cline { 2 - 6 } Older Adults & March & April & May & June & July \\
& $\mathbf{2 0 1 2}$ & $\mathbf{2 0 1 2}$ & $\mathbf{2 0 1 2}$ & $\mathbf{2 0 1 2}$ & $\mathbf{2 0 1 2}$ \\
\hline Positive Images & 26 & 23 & 25 & 29 & 30 \\
Negative Images & 0 & 0 & 2 & 0 & 1 \\
Comical & 0 & 2 & 2 & 3 & 3 \\
Total & 26 & 25 & 29 & 32 & 34 \\
Percent Positive & $100 \%$ & $92 \%$ & $86 \%$ & $90 \%$ & $88 \%$ \\
\hline
\end{tabular}

We also noted that the images of older adults in Zoomer magazine are almost always white skinned despite the fact that by 2006, 1 in 6 Canadians belonged to a visible minority group [37] (See Table 2).

Table 2. Visible Minorities in Zoomer Magazine March-July 2012.

\begin{tabular}{cccccc}
\hline \multirow{2}{*}{$\begin{array}{c}\text { Images of Older } \\
\text { Adults }\end{array}$} & March & April & May & June & July \\
& $\mathbf{2 0 1 2}$ & $\mathbf{2 0 1 2}$ & $\mathbf{2 0 1 2}$ & $\mathbf{2 0 1 2}$ & $\mathbf{2 0 1 2}$ \\
\hline White & 23 & 23 & 26 & 30 & 34 \\
Non-White & 3 & 2 & 3 & 2 & 0 \\
Total & 26 & 25 & 29 & 32 & 34 \\
\hline
\end{tabular}

Nor were there any images of older adults that overtly indicated poverty or financial distress of any kind. On the contrary, the older adults pictured in Zoomer magazine take cruises, have expensive dental treatment, and need financial estate planners to help them pass down their wealth. Further, advertisements in Zoomer magazine showed as many young and very young people as older adults and the images of older adults used were overwhelmingly positive and almost always white skinned (see Table 3). The one exception concerned the very few ads for medical products or nursing home care. These ads almost always showed older adults in situation of infirmity and distress.

\section{Negative Images}

Notwithstanding the increasing frequency of positive images of aging bodies in the media, negative images of older adults still exist, either as icons of the societal anomie engendered by aging populations [20,23,38] (see Figure 5), or as stereotypes showing adults through the lens of decline and diminished value” [14,20,39-43] (see Figure 6), or, as in the case of the Geezerade advertising campaign, aging bodies are presented as the 'grotesque' [1,2]. 
Table 3. Older Adults and Younger people in Zoomer Magazine Advertisements March-July 2012.

\begin{tabular}{|c|c|c|c|c|c|}
\hline \multirow{2}{*}{$\begin{array}{l}\text { Images of older adults and young } \\
\text { people in Advertisements }\end{array}$} & \multicolumn{5}{|c|}{ Zoomer Magazine } \\
\hline & $\begin{array}{c}\text { March } \\
2012\end{array}$ & $\begin{array}{c}\text { April } \\
2012\end{array}$ & $\begin{array}{l}\text { May } \\
2012\end{array}$ & $\begin{array}{l}\text { June } \\
2012\end{array}$ & $\begin{array}{l}\text { July } \\
2012\end{array}$ \\
\hline Images of older adults & 16 & 13 & 16 & 14 & 11 \\
\hline Images of young people & 15 & 9 & 12 & 15 & 11 \\
\hline Mix of older adults and young people & 5 & 3 & 3 & 3 & 3 \\
\hline Total & 36 & 25 & 31 & 32 & 25 \\
\hline Positive Images of older adults & 15 & 12 & 14 & 13 & 10 \\
\hline Negative Images of older adults & 1 & 1 & 2 & 1 & 1 \\
\hline Total & 16 & 13 & 16 & 14 & 11 \\
\hline White older adults & 16 & 13 & 15 & 12 & 10 \\
\hline Non-white older adults & 0 & 0 & 1 & 2 & 1 \\
\hline Total & 16 & 13 & 16 & 14 & 11 \\
\hline
\end{tabular}

Figure 5. Online Article: America’s Aging Labor Force.

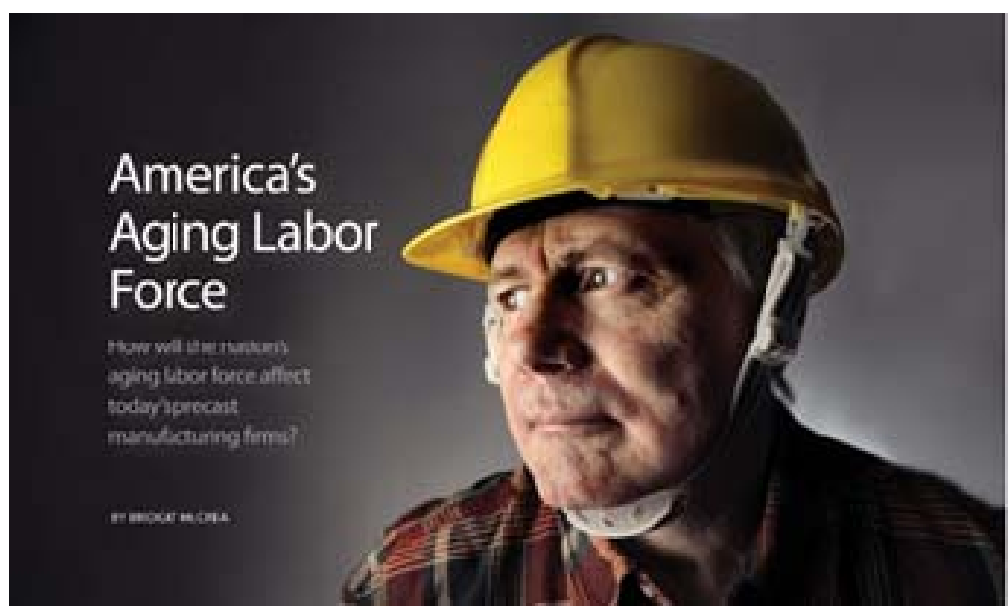

Bridget McCrea, National Precast Concrete Association (NPCA).

Figure 6. CARP Health Wizard Advertisement.

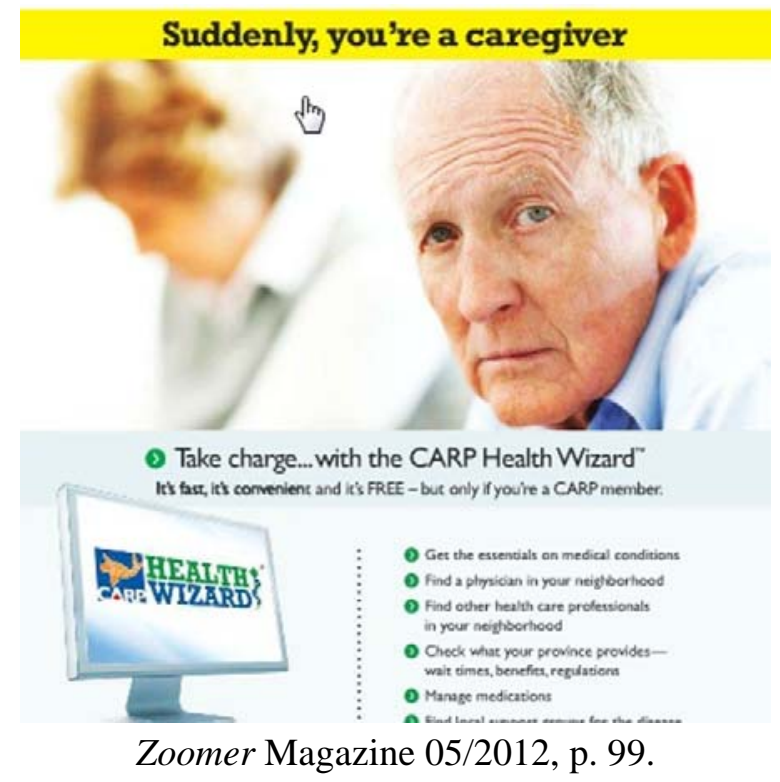




\section{The Geezerade Campaign}

During the spring and summer of 2011 we were engaged in research on aging in place for seniors in New Brunswick, Canada [44,45]. As part of these projects, we conducted face-to-face interviews with seniors in the province. This required driving what were sometimes long distances to the homes of seniors we were to interview where the only rest stops were the Irving owned convenience stores attached to gas stations. It was during this field work that we became aware of the Geezerade advertising campaign, which used a series of posters displayed in Circle K (New Brunswick) and Couch-Tard (Quebec) convenience stores that showed images of a child merged with that of an older person creating, in the parlance of the ad campaign, 'Geezers' in order to sell Slushies, a flavored frozen drink made of crushed ice and sugary syrup. The notion meant to be conveyed by the ad is that by drinking a Slushie a child would be frozen into old age (see Figures 7 and 8).

Figure 7. Circle-K Geezerade Advertising Poster.

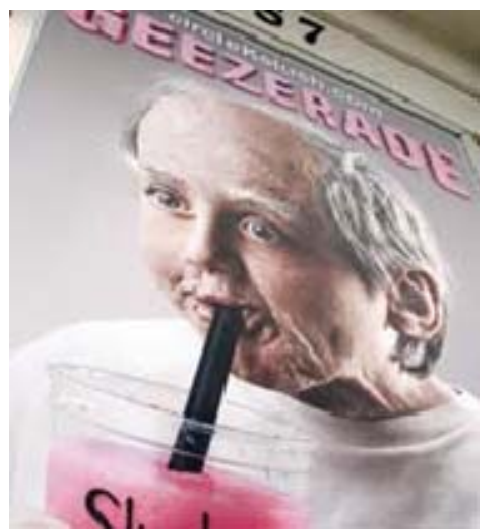

Geezerade Advertisement. The Weekly News, Summer 2011.

Figure 8. Geezerade Online Advertisement Summer 2011.

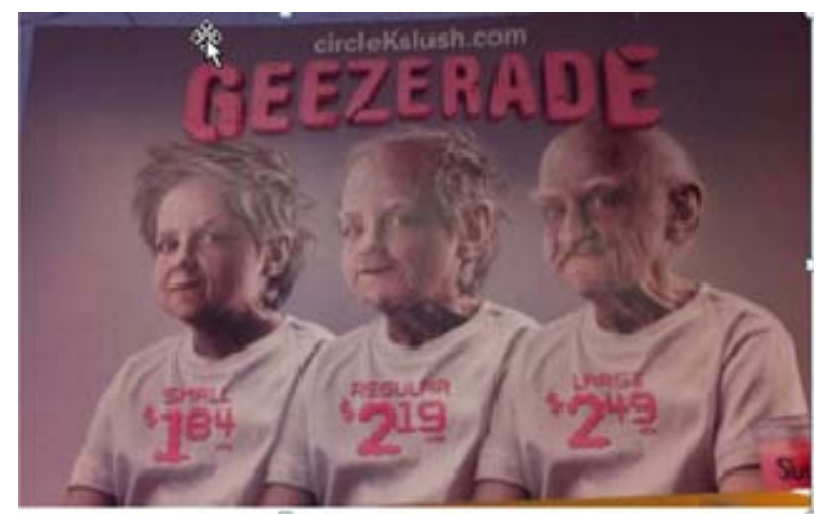

Sage Play. "It Feels Good to be Old at Heart” (Blog).

As McHugh argues, "images and scripts can be interpreted not only as marketing ploys and strategies but more deeply, as mould and mirror of ageist attitudes and cultural values” ([23], p. 166). Thus, the Geezerade ad campaign reflects a particularly negative image of older adults that we can conceptualize as a grotesque that is rooted in ageism in order to sell a product. The grotesque is a controversial technique that is increasingly used in advertising [46]. For example, witness the 
Benneton clothing advertisements featuring David Kirby dying from AIDS [47], the heroin chic fashion advertisements used by Calvin Klein [48], the Spanish Honda car part campaigns making use of merged photos of animal and human faces [49], or depictions of bestiality in a French AIDS public service campaign [50]. In the case of the Geezerade ads the grotesque involves, the merging of images of a child and an older adult, and represents a marked "violation of the social order" ([1], p. 9) as it managed to offend not only on the basis of ageism but also ableism by not only insulting older adults but also people who live with or are concerned about Progeria (Hutchinson-Gilford Progeria Syndrome), a genetic disease that causes children to appear as if they have aged prematurely [51]. Over the course of the campaign significant public protest emerged. Complaints were made in the news media, Internet protest posters were created, and a "Stop-Geezerade" Face Book page was set up that had garnered 100 members within twenty-four hours [52,53]. One posting on the "Stop-Geezerade" Face Book page reads:

The offensive product in question is a Circle $\mathrm{K}$ brand called Geezerade. They would not get away with branding a drink product Jewboyade, Coonade, Homoade or Whoreade so why are have they chosen to use an offensive term for seniors as part of their brand [54,55]?

Another protest poster likened Circle K to the Klu Klux Klan, showing white robed figures and the text “Circle KKK Hatin’ On The Old Folks” [56]. Craig Norris, a resident of Moncton and creator of the Stop-Geezerade Facebook page told CBC news that he found the Geezerade campaign "disrespectful of seniors and... 'deeply offensive”" [52]. He decided to start the Facebook page after hearing children laughing at the 'geezers' depicted in the ads. In his words:

A couple of kids from our in-home daycare walked by and when they saw the photo, one kid said, 'Oh look at the geezer.' Then another kid said, 'There's a geezer on the screen' and they all started to laugh and it just kind of made me cringe [52].

However, a kind of cultural lag shaped Circle-K's initial response to the public criticism and they seemed unaware of the inherent ageism in their ad campaign. For example, Couch-tard (Circle $\mathrm{K}$ in Quebec) replied to a complaint made by Suzanne Dupuis-Blanchard by stating that "they had researched the word "geezer" and found nothing wrong with its use” [57]. In an email to Couch-tard on May 11, 2012 she wrote:

I would like to voice my support to end this promotion. I wrote an email to Irving on Wednesday May 4th after seeing the poster in question. Couche-tard called me the next day to explain that they had researched the word "geezer" and found nothing wrong with its use. I've been interviewed by Radio-Canada and they gave Couche-tard the opportunity to respond to my request of removing this promotion; they responded that they would not be removing the poster because young people are attracted to this images. I've asked different young people in the last day about the poster and they do not understand the message. I also wrote a letter to the editor at the Times \& Transcript. Therefore, I am again, asking for the removal of these posters [57].

Similarly, when Craig Norris contacted Circle K to "complain about the advertisement, they called him back and told him they would keep his concerns in mind for their next campaign" rather than agree to take down the ads, which was Norris' goal [52]. However, in the wake of mounting criticism and public condemnation, the campaign was finally pulled at the end of June 2011 [58]. In ending the 
Geezerade ad campaign the company issued a new poster featuring a glass of Slushie with text stating: "When summer ends, Geezerade ends. Sorry, from now on you'll have to age naturally" (emphasis ours) [59]. What is remarkable about this poster is that Irving either wittingly or unwittingly admits that their Ads invoked the "unnatural" consistent with classic meaning of the grotesque.

\section{Conclusions}

Research has shown that older adults are portrayed more diversely and in more positive terms in textual references to them in the media today than in the past decade $[10,20,21,42]$. However, our analysis found few images of 'old, old' people, almost no images of older people of color, and no Images of poor old people in Zoomer magazine. These positive images therefore are problematic as they do not account for the diversity of seniors in society. Instead they reflect anti-aging ethos that is ageist in its devaluing of old age, and are decidedly class bound [10,20,23,24,42]. In them the only truly positive aging is anti-aging. As Rozanova concludes:

The ideal aging citizen is someone... that... remains youthful as long as possible, contributes to the economy as a smart consumer and as an active participant in productive activities, and stays healthy to avoid accessing healthcare and other public services ([20], p. 220).

However, you cannot stay young forever if you cannot afford to buy the products and services that defy age $[14,19,20,42]$. Moreover, negative images of seniors disparaging the "the act of growing older itself” ([14], p. 67) have not disappeared, and to them we can add the 'grotesque' representation of aging depicted in the Geezerade advertising campaign [42]. Thus, we are left with a binary model of aging made up of negative and positive images of older adults, both of which, in the context of aging populations, reflect enduring ageism in addition to the "values of consumerism" ([60], p. 134) in class-based society [23]. Such a model limits the categories through which we understand the aging body and fails to account for the diversity of senior's bodies in society. This binary model of stereotypes of aging bodies persists despite the aging population and third age ideologies [61]. This is in no small part because didactic oppositional models are deeply ingrained as explanatory devices in Western culture. Cartesian dualism places mind and body in opposition; Durkheim and Douglas point out the significance of the binary concepts of the sacred and profane and those of danger and purity for social order; and despite the women's movement in addition to gay rights and LGTB activism, the media still largely reflects a binary model of gender allowing only for the masculine and feminine [62-64]. Thus, it is not surprising that a binary model of ageing remains entrenched in contemporary Western society; and thus remains a limiting and potentially constraining force on perceptions of aging bodies.

\section{Acknowledgements}

This paper is based on a presentation given in the RC11 Sociology of Aging-Images of Aging session, at the 2nd International Sociological Association (ISA) World Forum, Buenos Aries, Argentina, 1-4 August 2012. Further we are grateful to The New Brunswick Health Research Foundation, The Government of New Brunswick, and The University of New Brunswick for their funding of the projects that gave rise to this paper. 


\section{References and Notes}

1. Coleman, A.D. The Grotesque in Photography; Summit Books: New York, NY, USA, 1977.

2. Bakhtin, M. Rabelais and His World; Indiana University Press: Bloomington, IN, USA, 1984.

3. Ball, M.; Smith, G. Analyzing Visual Data; Sage: Newbury Park, CA, USA, 1992.

4. Smith, G. Gender Advertisements Revisited: A Visual Sociology Classic. Electron. J. Sociol. 1996, 2. Available online: http://www.sociology.org/content/vol002.001/smith.html (accessed on 16 July 2011).

5. Also surprising given the increasing use of methodologies to analyze images such as Photovoice. See Catalani, C.; Minkler, M. Photovoice: A Review of the Literature in Health and Public Health. Health Edu. Behav. 2010, 37, 424-451.

6. Said, E.W. Orientalism, 25th anniversary ed.; Pantheon Books: New York, NY, USA, 1978.

7. Bell, P.; Milic, M. Goffman’s Gender Advertisements Revisited: Combining Content Analysis with Semiotic Analysis. Visual Communic. 2002, 1, 203-222.

8. Buffington, D.; Fraley, T. Skill in Black and White: Negotiating Media images of Race in a Sporting Context. J. Commun. Inquiry 2008, 32, 292-310.

9. Bytheway, B. Unmasking Age: The Significance of Age for Social Research; Policy Press: Bristol, UK, 2011.

10. Lumme-Sandt, K. Images of Ageing in a 50+ Magazine. J. Aging Stud. 2011, 25, 45-51.

11. Ylanne, V. Representing Ageing: Images and Identities; Palgrave Macmillan Houndmills: Basingstoke, UK, 2012.

12. Blumer, H. Symbolic Interactionism: Perspective and Method; Prentice Hall Inc.: New Jersey, NY, USA, 1969.

13. Tiggemann, M. Body images across the adult life span: Stability and change. Body Images 2004, 1, 29-41.

14. Ellis, S.R.; Morrison, T.G. Stereotypes of Ageing: Messages Promoted by Age-Specific Paper Birthday Cards Available in Canada. Int. J. Aging Hum. Dev. 2005, 61, 57-73.

15. Goffman, E. The Interaction Order. Am. Sociol. Rev. 1983, 48, 1-17.

16. Goffman, E. Gender Advertisements; Harper and Row: New York, NY, USA, 1976; p. 3.

17. Altheide, D.L. Ethnographic content analysis. Qual. Sociol. 1987, 10, 65-77.

18. Corbin, J.M.; Strauss, A.L. Grounded theory research: Procedures, Canons, and evaluative criteria. Qual. Sociol. 1990, 13, 3-21.

19. Vickers, K. Aging and the Media: Yesterday, Today, and Tomorrow. Calif. J. Health Promot. 2007, 5, 100-105.

20. Rozanova, J. Discourse of Successful Aging in the Globe and Mail: Insights From Critical Gerontology. J. Aging Stud. 2010, 24, 213-222.

21. Zhang, Y.B.; Harwood, J.; Williams, A.; Ylänne-McEwen, V.; Wadleigh, P.M.; Thimm, C. The Portrayal of Older Adults in Advertising: A Cross-National Review. J. Lang Soc. Psychol. 2006, 25, 264-282.

22. Cole, T.R. The Journey of Life: A Cultural History of Aging in America; Cambridge University Press: Cambridge, MA, USA, 1992.

23. McHugh, K.E. Three Faces of Ageism: Society, Image and Place. Ageing Soc. 2003, 23, 165-185. 
24. Rozanova, J.; Northcott, H.C.; McDaniel, S. Seniors and Portrayals of Intra-Generational and Inter-Generational Inequality in the Globe and Mail. Can. J. Aging, 2006, 25, 373-386.

25. Lee, M.M.; Carpenter, B.; Meyers, L.S. Representations of Older Adults in Television Advertisements. J. Aging Stud. 2007, 21, 23-30.

26. Miller, D.W.; Leyell, T.S.; Mazachek, J. Stereotypes of the Elderly in U.S. Television Commercials from the 1950s to the 1990s. Int. J. Aging Hum. Dev. 2004, 58, 315-340.

27. Vesperi, M.D. Introduction: Media, Marketing, and images of the older person in the information age. Generations 2001, 25, 5-9.

28. Jones, I.R.; Hyde, M.; Victor, C.R.; Wiggins, R.D.; Gilleard, C.; Higgs, P. Ageing in a Consumer Society: From Passive to Active Consumption in Britain; Policy Press: Bristol, UK, 2008.

29. Vesperi, M.D. Forty-Nine Plus: Shifting images of Aging in the Media. In Reinventing Aging. Harvard School of Public Health-MetLife Foundation Initiative on Retirement and Civic Engagement; Center for Health Communication, Harvard School of Public Health, Baby Boomers and Civic Engagement, MetLife Foundation, 2003; pp. 125-154

30. Cutter, J.A. Specialty Magazines and the Older Reader. Generations 2001, 25, 13-15.

31. Featherstone, M.; Hepworth, M. Images of Aging. In Encyclopedia of Gerontology; Birren, J.E., Ed.; Elsevier: Amsterdam, The Netherland, 2007; pp. 735-742.

32. Vincent, J.A. Ageing Contested: Anti-Ageing Science and the Cultural Construction of Old Age. Sociology 2006, 40, 681-698.

33. Williams, A.; Ylanne, V.; Wadleigh, P.M. Selling the 'Elixir of Life': Images of the Elderly in an Olivio Advertising Campaign. J. Aging Stud. 2007, 21, 1-21.

34. Zoomer Magazine, April 2012, p. 28.

35. Zoomer Magazine, March 2012, p. 28.

36. Zoomer Magazine, July 2012, p. 14.

37. CBC. 1 in 6 Canadians is a visible minority: StatsCan-South Asians Top Chinese as Largest visible minority group. CBC News Online, 2 April 2008. Available online: http:/www.cbc.ca/ news/canada/story/2008/04/02/stats-immigration.html (accessed on 15 July 2012).

38. Durkheim, E. The Division of Labor in Society; Free Press: New York, NY, USA, 1997.

39. Grenier, A. Constructions of Frailty in the English Language, Care Practice and the Lived Experience. Ageing Soc. 2007, 27, 425-445.

40. MacRae, F. Disney’s villains ‘give children negative images of the elderly’. Mail Online, 31 May 2007. Available online: http://www.dailymail.co.uk/news/article-458808/Disneys-villainschildren-negative-images-elderly.html (accessed on 24 June 2011).

41. McGlynn, K. This week in ridiculous stock photos: Old people using computers. The Huffingtton Post, 15 March 2011. Available online: http://www.huffingtonpost.com/2011/03/15/this-week-inridiculous-stock-photos_n_835869.html\#s253779 (accessed on 24 June 2011).

42. Milner, C.; Van Norman, K.; Milner, J. The Media’s Portrayal of Ageing. In Global Population Ageing: Peril or Promise? World Economic Forum: Geneva, Switzerland, 2011. Available online: http://www3.weforum.org/docs/WEF_GAC_GlobalPopulationAgeing_Report_2012.pdf (accessed on 18 July 2012).

43. Thimm, C. Advertising and the Older Generation: Humourous or Degrading? In Media Res: A Media Commons Project, 23 March 2009. Available online: http://mediacommons.futureofthe 
book.org/imr/2009/03/22/advertising-and-older-generation-humerous-or-degrading (accessed on 24 June 2011).

44. Dupuis-Blanchard, S.; Simard, M.; Gould, O.; Villalon, L. Les défis et les Enjeux Liés au Maintien à Domicile des Aînés: Une Étude de Cas en Milieu Urbain Néo-Brunswickois. Rapport de Recherche; Université de Moncton: Moncton, New Brunswick, Canada, 2011.

45. Low, J.; Thériault, L.; Luke, A.; Hollander, M.; van den Hoonaard, D. Sustainable Home Support for Seniors in New Brunswick: Insights From Seniors and Social Workers. Department of Sociology, University of New Brunswick: Fredericton, Canada, 2011.

46. Phillips, B.J.; McQuarrie, E.F. Narrative and Persuasion in Fashion. J. Consum. Res. 2010, 37, 368-392.

47. Duncan. Benetton Pieta in AIDS Campaign. The Inspiration Room, 7 April 2007. Available online: http://theinspirationroom.com/daily/2007/benetton-pieta-in-aids-campaign/ (accessed on 17 July 2012).

48. Grant, V. Still Shocking. The Kit Beauty \& Fashion, 29 September 2011. Available online: http://www.thekit.ca/beauty/body/a-ck-history/ (accessed on 18 November 2012).

49. Grotesque Animal Faces. TrendHunter Marketing. Available online: http://www.trendhunter.com/ trends/grotesque-faces-hondas-use-original-parts-campaign (accessed on 18 November 2012).

50. 40 Animalistic Ads. TrendHunter Marketing. Available online: http://www.trendhunter.com/ slideshow/40-animalistic-ads\#2 (accessed on 18 November 2012).

51. MNT. What is progeria? Medical News Today, 13 May 2009. Available online: http://www.medicalnewstoday.com/articles/146746.php (accessed on 18 July 2012).

52. CBC. Geezerade ad campaign angers Moncton man. CBC News online, 24 May 2011. Available online: http://www.cbc.ca/news/canada/new-brunswick/story/2011/05/24/nb-geezeraid-campaign. html (accessed on 17 July 2011).

53. Replyz. Can anyone explain to me the Circle K marketing and ad campaign with slush / “Geezerade”? Replyz Tue, May 24 2011. Available online: http://replyz.com/c/10563745-cananyone-explain-to-me-the-circle-k-marketing-and-ad-campaign-with-slush-geezerade (accessed on 17 June 2011).

54. Stop Geezerade campaign Facebook page. Available online: http://www.facebook.com/pages/ Boycott-Irving-Gas-Circle-K-Stores-Ridicule-Of-seniors/122830681131794?sk=info (accessed on 17 June 2011).

55. What if was called Coon-Ade? Medical News Today, 2009. Available online: http://www.medicalnewstoday.com/articles/146746.php (accessed on 17 June 2011).

56. Circle KKK-Hatin' On The Old Folks. Geezerade protest poster since removed from the internet.

57. Text of an e-mail message sent by Suzanne Dupuis-Blanchard to Couche-Tard on 11 May 2011, asking them to end the Geezerade campaign.

58. D’Entremont, Y. Geezarade icy slush campaign gets cold shoulder. Halifax News Net, 15 June 2011. Available online: http://www.halifaxnewsnet.ca/News/2011-06-15/article-2586526/ Geezarade-icy-slush-campaign-gets-cold-shoulder--/1 (accessed on 24 June 2011).

59. Circle, K. Poster announcing end of the Geezerade campaign. Available online: http//www.circlekslush.com (accessed on 27 July 2012). 
60. Rozanova, J. Newspaper Portrayal of Health and Illness Among Canadian Seniors: Who Ages Healthily and at What Cost. Int. J. Ageing Later Life 2006, 1, 111-139.

61. Komp, K.A. New images of Old Age: The Case of Third Age Societies. Paper presented in the RC11 session: Images of Old Age at the 2nd ISA Forum of Sociology, Buenos Aires, Argentina, 1-4 August 2012.

62. Descartes, R. Discourse on the Method of Rightly Conducting the Reason and Seeking the Truth in the Sciences; P. F. Collier \& Son Company: New York, NY, USA, 2001.

63. Douglas, M. Purity and Danger: An Analysis of Concepts of Pollution and Taboo; Routledge and Keegan Paul: London, UK, 1966.

64. Durkheim, E. The Elementary Forms of the Religious Life; The Free Press: New York, NY, USA, 1912.

(C) 2013 by the authors; licensee MDPI, Basel, Switzerland. This article is an open access article distributed under the terms and conditions of the Creative Commons Attribution license (http://creativecommons.org/licenses/by/3.0/). 